\title{
TUTKIJA VAI SOSIAALITYÖNTEKIJÄ? \\ Autoetnografinen TARKASTELU \\ TUTKIJASOSIAALITYÖNTEKIJÄN POSITIOISTA
}

Eeva Rossi: YTL, tutkija, laillistettu sosiaalityöntekijä, sosiaalityön jatko-opiskelija, Lapin yliopisto

erossi@ulapland.fi

Janus vol. 29 (1) 2021,37-53

(1)

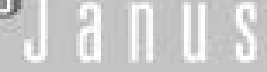

\section{Tiivistelmä}

Tutkimuksessa tarkastellaan tutkijasosiaalityöntekijän toiminnallista ja tutkimuksellista asemoitumista iäkkäiden asumispalvelukeskuksessa. Tutkimus paikantuu etnografian autoetnografiseen perinteeseen. Artikkeli pohjautuu kirjoittajan kokemuksiin tutkijasosiaalityöntekijänä ja aineistona ovat päiväkirjamerkinnät vuosien 2014-2016 kenttäjaksolta. Tutkimuksessa kysytään, millaisia positioita tutkijasosiaalityöntekijän rooliini asumispalvelukeskuksessa liittyy ja miten ne paikantuvat suhteessa organisaatioon, henkilökuntaan ja asukkaisiin. Tutkimuksessa positio paikantui kolmeen toisiinsa liittyvään käsitepariin: virallinen - epävirallinen, ulkopuolinen - sisäpuolinen ja neutraali - hyvän tuottaja. Ensimmäinen käsitepari kuvaa tutkijasosiaalityöntekijän asemaa suhteessa työyhteisöön sekä organisaatioon. Ulkopuolinen kuvaa tutkijan kokemusta, joka osin liittyy epäviralliseen asemaan. Sisäpuolisuus liittyy asukkaiden rinnalla oloon ja heidän tukemiseensa. Kolmas käsitepari kuvaa tutkimuksen toteuttamista. Hyvän tuottaminen on asukkaiden auttamista. Neutraali etäännyttämistä kokemuksista.

\section{JOHDANTO $^{1}$}

Sosiaalityössä käytännön, tutkimuksen ja tiedon tuotannon yhteys on ollut pitkään keskeinen teema, johon on liittynyt pohdintaa käytännöissä toimivista sosiaalityöntekijöistä tutkijoina ja kirjoittajina (esim. Mutka 1998; Driessens ym. 2011; Julkunen 2011; HE $5 / 2020)$. Myös tutkimus ja sosiaalityö toimintana on usein rinnastettu toisiinsa, jolloin molemmat on nähty ongelmanratkaisuprosesseina (esim. Scourfield 2001). Toisaalta on myös todettu, etteivät työntekijät tutki, vaan arvioivat ja tukevat ihmisten elämäntilanteita ja niiden muutoksia (Holstein \& Gubrium 2000). Tuolloin kyse on sosiaalityön tutkimuksen ja käytäntöjen erilaisista tehtävistä. Tutkimuksen tehtävät liittyvät tiedon tuottamiseen sekä abstraktien käsitteiden, ilmiöiden ja teoreettisten näkökulmien esittämiseen (Mikkonen ym. 2016), kun taas esimerkiksi gerontologisen sosiaalityön tehtävät liittyvät iäkkäiden toimintakyvyn, hyvinvoinnin ja kompetenssien tukemiseen sekä eri elämäntilanteissa auttamiseen ja muutosten mahdollistamiseen (Koskinen \& Seppänen 2013).

Tässä artikkelissa sosiaalityön käytännöt ja tutkimus yhdistyvät siten, että tarkastelen toimintaani tutkijasosiaalityöntekijänä iäkkäiden asumispalvelukeskuksessa. Artikkelini kiinnittyy kokemuksiini sosiaalityöntekijänä, yliopisto-opettajana ja jatko-opiskelijana. Noin 25 vuotta kestäneen työurani eri vaiheissa olen pohtinut sosiaalityön 
käytäntöjen ja oman työni tutkimista. Artikkelini kohdentuu vaiheeseen, jolloin toimin yliopisto-opettajana ja olin mukana iäkkäiden asumispalvelukeskuksessa (jatkossa Keskus) toteutetussa projektissa, jonka tavoitteena oli tukea asukkaiden hyvinvointia ja yhteisöllisyyttä. Opettajan tehtäviini kuului myös opiskelijoiden käytännön jaksoon liittyvä opetus sekä oman tutkimuksen tekeminen. Keskuksen johdon kanssa päätimme kokeilla näiden kahden osaalueen yhdistämistä: toimin yksikköön käytännönjaksolle menevän opiskelijan käytännön opettajana sekä tutkijasosiaalityöntekijänä keräten samalla väitöskirjatutkimuksen aineistoa. ${ }^{2}$ Keskuksessa ei työskennellyt sosiaalityöntekijää, mutta kohtaamiset asukkaiden ja henkilökunnan kanssa olivat saaneet minut pohtimaan asukkaiden sosiaalityöllisiä tarpeita. Tutkijana tavoitteenani oli tarkastella näiden tarpeiden määrittymistä asukkaiden ja sosiaalityöntekijän kohtaamisissa. Toisena tavoitteenani oli tarkastella sosiaalityöntekijän tutkijana toimimisen mahdollisuuksia. Kysymystä asukkaiden tarpeista ja gerontologisesta sosiaalityöstä olen tarkastellut aiemmassa artikkelissani (Rossi 2018). Tässä artikkelissa keskityn analysoimaan kokemuksiani tutkijasosiaalityöntekijänä toimimisesta.

Käytäntöjen ja tutkimuksen yhteys on vahva sosiaalityön käytäntötutkimukseksi kutsutussa tutkimustraditiossa (Satka ym. 2005; Driessens ym. 2011; Julkunen 2011). Tutkimuksessani on yhtymäkohtia erityisesti käytäntötutkimuksen (practice research) käytäntötutkija (practitioner research) orientaatioon. Aiheeni on noussut käytännöistä, toimin itse tutkijana, tutkimukseni kenttänä on käytäntö ja tutkimuksessani yhdistyvät interventio ja tutkimus (Shaw \& Lunt 2018; Julkunen 2011; Uggerhøj 2011). Tutkimuksestani sen sijaan puuttuvat eräät käytäntötutkimukseen usein liitetyt piirteet, kuten sosiaalityön käytäntöjen ja työskentelyn kehittäminen, yhteistutkijuus sekä toimintatutkimuksellinen lähestymistapa (esim. Julkunen 2011; Driessens ym. 2011).

Vaikka tutkimukseni kiinnittyy sosiaalityön käytäntöihin, kohdistuu artikkelini tutkijasosiaalityöntekijänä toimimisen kokemuksiini. Tutkimukseni paikantuu etnografian autoetnografiseen perinteeseen. Autoetnografia on kokemuksen tutkimusta, jossa kokemus viittaa tutkijan omiin kokemuksiin. Koska olen toiminut tutkijasosiaalityöntekijänä, olen itse tutkimuksen kohde, mutta myös tutkija (esim. Rissanen 2015). Chang kollegoineen (2012) toteaa, että autoetnografia on itsensä tutkimista ollen kuitenkin yhteydessä tutkijan kulttuuriseen kontekstiin. Minun autoetnografiani konteksteina ovat sosiaalityön käytännön ja tutkimuksen kulttuurit. Autoetnografia mahdollistaa erilaisten roolien tarkastelun (Jensen-Hart \& Williams 2010) ja sen avulla on tutkittu esimerkiksi kokemuksia sairastumisesta ja kuntoutumisesta (Rissanen 2015), tutkimuksellisista kysymyksistä (Ettorre 2013) ja sosiaalityön opetuksesta (Jensen-Hart \& Williams 2010; Watts 2015). Artikkelissani tarkastelun kohteena ovat sosiaalityön tutkijana ja sosiaalityöntekijänä toimimiseni sekä niihin liittyvät roolit.

Se, että käytän käsitettä tutkijasosiaalityöntekijä, tuo eksplisiittisesti esiin toimintaani liittyneen kaksoisroolin: tutkijuuden ja sosiaalityöntekijyyden. Tutkijana ja sosiaalityöntekijänä toimi- 
miseen liittyy erilaisia tehtäviä, asemia, oikeuksia ja velvollisuuksia (Goffman 1971).Tarkastelen tutkimuksessani näitä kahta roolia ja tuon tietoa niiden yhdistämisestä osallistuen näin keskusteluun sosiaalityöntekijän tutkijana toimimisesta (esim. HE 5/2020). Toimintani ja roolieni tarkastelun analyysissa hyödynnän positioteoriaa (van Lagenhove \& Harré 1999). Position käsitteeseen liittyy ymmärrys siitä, että sosiaalisen elämän eri rooleihin kuuluu erilaisia oikeuksia ja velvollisuuksia tehdä ja sanoa asioita (moral positioning), mutta myös yksilölliseen elämänkulkuun ja aiempiin kokemuksiin liittyviä tekijöitä (personal positioning). Positiot ovat kontekstiin sidottuja, tilannekohtaisesti vaihtuvia ja jopa lyhytaikaisia, mutta itsensä positiointiin liittyy myös omia aiempia kokemuksia ja oma elämänkulku. (Harré ym. 2009; van Lagenhove \& Harré 1999.)

Kysyn tutkimuksessani, millaisia positioita tutkijasosiaalityöntekijän rooliini Keskuksessa liittyy ja miten ne paikantuvat suhteessa organisaatioon, sen henkilökuntaan ja asukkaisiin. Tarkastelen suhdettani yhteisöön sekä toimintaani liittyviä oikeuksia ja velvollisuuksia (moral positioning), mutta myös yksilöllisiä tekijöitä (personal positioning). Position käsite mahdollistaa toiminnan ja suhteen kontekstisidonnaisen tarkastelun, koska analyysini kohdentuu toimintaani tutkijasosiaalityöntekijänä uudessa yhteisössä, jossa minulla ei ollut vakiintunutta asemaa sosiaalityöntekijän työkokemuksestani huolimatta. Kyse on itsepositioinnista, joka perustuu kokemuksiani kuvaavan aineiston analyysiin. Artikkelini on osin myös metodologinen ja epistemologinen tarkastelu.Tarkastelen, mistä paikasta käsin tutkimukseni tuottaa tietoa, sillä paikannan itseäni suhteessa tutkimukseen ja tutkittaviin. Tutkija näkee maailman aina jostakin ottamastaan tai saamastaan positiosta. (Ronkainen 1999; Harré ym. 2009.) Sosiaalityön tutkimuksen näkökulmasta tuon paikan tunnistaminen on tärkeää tuotetun tiedon tulkitsemiseksi.

Artikkelini etenee siten, että kuvaan ensin sitoumuksiani autoetnografiaan, minkä jälkeen on niin sanotun avauskertomuksen (Eräsaari 1995, 51) vuoro, eli kerron tutkimuskentälle pääsystä ja aineiston hankinnasta. Varsinaiset tulosluvut pohjautuvat päiväkirjamerkintöjeni analyysiin. Ensimmäisessä tulosluvussa tarkastelen suhdettani organisaatioon ja työyhteisöön, ja toisessa asukkaisiin. Lopuksi teen tulosten yhteenvedon ja pohdin tutkimukseni antia.

\section{Autoetnografia tutkimuksen LÄHESTYMISTAPANA}

Autoetnografia lähestymistapana pyrkii kuvaamaan ja systemaattisesti analysoimaan (graphy) henkilökohtaisia kokemuksia (auto), jotta voidaan ymmärtää kulttuurisia kokemuksia (ethno) (Ellis ym. 2011). Tutkiva subjekti on autoetnografiassa keskeisessä asemassa, eikä tutkittavaa ja tutkijaa eroteta toisistaan. Tutkimus keskittyy tutkijaan ja meihin, ei toisiin tai tuntemattomaan yhteisöön. (Markuksela 2013, 102-115.) Tutkijan omat kokemukset ja eletty elämä ovat tutkimuksen kohteena, jolloin kokemukset ja tunteet ovat tutkimuksen keskiössä (Ellis \& Flaherty 1992; ks. Eräsaari 1995, 63), eikä kyse ole vain tutkijan paikantamisesta (esim. 
Pitkänen 2011; Garthwaite 2016; Vincett 2018).

Leon Anderson (2006) on erottanut evokatiivisen (evocative) ja analyyttisen (analytic) autoetnografian. Ensin mainittu kiinnittyy konstruktivistiseen perinteeseen, ja siinä on keskeistä lukijan tunteiden herättäminen tarinallisuuden kautta. Analyyttinen autoetnografia keskittyy kokemusta yleisemmän sosiaalisen ilmiön tutkimiseen ja analysointiin. Andersson (2006) toteaa sen kiinnittyvän realistiseen perinteeseen. Ellis ja Bochner (2006) ovat kritisoineet Anderssonin ajattelua todeten analyyttisen autoetnografian olevan vain yksi konventionaalisen realistisen etnografian muoto. Minä tarkastelen kokemuksiani tutkijasosiaalityöntekijänä toimimisesta, mutta jätän kokemuksiini liittyvien tunteiden tarkastelun vähemmälle ja kiinnityn näin enemmänkin autoetnografian analyyttiseen perinteeseen (Andersson 2006).

Tarkastelen tutkimuksessa päiväkirjamerkintöjäni Keskuksessa toimimiseni ajalta vuosina 2014-20163. Olen kirjoittanut päiväkirjat käsin A5-kokoisiin muistikirjoihin, ja tekstiä on yhteensä 222 sivua. Päiväkirjani ovat havainto- ja reflektiopäiväkirjojen yhdistelmiä, joihin kirjasin havaintojani ja kokemuksiani sekä niiden herättämiä ajatuksia. Päiväkirjamerkinnät kuvaavat toimintaani ja ovat minun, kenttätyöntekijän, elettyjen kokemusten ja niihin liittyvien tunteiden kuvauksia sekä eräänlaisia reunahuomautuksia tai kommentteja tapahtumiin (Emerson ym. 2001). Siten tutkimukseni on Ellisin ja kumppaneiden (2011) käsittein refleksiivistä etnografiaa (reflexive ethnographies), jossa tutkimuskohteena ovat omat muistiin- panoni ja kuvaukseni. Kyse on myös pienistä tarinoista, henkilökohtaisista kertomuksista (personal narratives), jotka fokusoituvat tutkimukselliseen elämääni (mt.). Henkilökohtaiset kuvaukset ovat ikkuna maailmaan, jonka kautta tutkijat tulkitsevat omaa suhdettaan kulttuuriseen kontekstiinsa, mutta myös sitä, miten tämä konteksti antaa merkityksen heidän kokemuksilleen ja näkemyksilleen (Chang ym. 2012, 18 19). Tähän liittyy myös ajatus siitä, että kokemuksemme ja kertomuksemme niistä ovat sosiaalisiin ja kulttuurisiin konteksteihin sidoksissa olevia tulkintoja (Witkin 2014). Minun kohdallani kokemukset ja päiväkirjojen kertomukset ovat yhteydessä sosiaalityön ja tutkimuksen konteksteihin.

Minulla kirjoittamisen ja analyysin prosessi alkoi vuosia kenttäjakson jälkeen, jolloin palasin lukemaan päiväkirjamerkintöjäni. Autoetnografiassa kirjoittamisen ja tutkimuksen on todettu liittyvän tutkijan oivalluksiin, merkityksellisiin hetkiin. Kyse on tapahtumien ja muistojen valikoitumisesta, jossa henkilökohtaisuus ja subjektiivisuus ovat keskeisiä. Tutkija nostaa esiin hänelle merkitykselliset hetket. (Ellis ym. 2011.) Analyysin alkaminen vasta kenttäjakson jälkeen mahdollisti itseni osittaisen etäännyttämisen kokemuksistani ja sen myötä ulkopuolisen tarkastelun. Tutkijana otin etäisyyttä sisällä olijan subjektiivisiin kokemuksiin ja loin tarkempaa ymmärrystä (Witkin 2014).

Tapaani tarkastella ja analysoida päiväkirjamerkintöjäni voi kuvata sisällönanalyysiksi, joka liittyy analyyttiseen autoetnografiaan (Jensen-Hart \& Williams 2010). Analyysin ensimmäisessä vaiheessa luin päiväkirjoja useaan ker- 
taan ja samalla palasin niiden kirjoittamisen aikaisiin tunnelmiin. Toisessa vaiheessa etsin päiväkirjoista kuvauksia, joissa reflektoin tutkijasosiaalityöntekijän paikkaa, tiedon tuottamista sekä näihin kiinnittyviä eettisiä tarkasteluja. Tarkastelun ulkopuolelle jätin kuvaukset asukkaiden tarpeista. Kolmanneksi kirjoitin löytämäni kuvaukset ja niiden herättämät ajatukset tekstitiedostoiksi. Samaan aikaan kirjoitin alustavaa tulkintaa kuvauksista. Seuraavaksi tarkastelin päiväkirjojen ja tekstitiedostojen rinnalla samoihin tilanteisiin liittyviä asukaskohtaamisten muistiinpanoja. Tämä mahdollisti kuvausten kontekstoimisen kohtaamisiin ja niiden tapahtumiin. Kyse oli merkityksellisiin hetkiin liittyvän ymmärryksen lisäämisestä ja sen myötä aiemmassa vaiheessa löydettyjen kuvausten ja huomioiden analyysin tarkentamisesta. Samalla analyysini tarkentui kohdistuen tutkijan ja sosiaalityöntekijän rooleihini ja asemaani yhteisössä sekä gerontologisen sosiaalityön yleisiin kysymyksiin. Analyysi jatkui tarkastelemalla tekstitiedostoissa olevia kuvauksia ja pohtimalla, mitä ja millaista suhdetta niissä kuvataan, mistä roolista ja toiminnasta kuvauksissa on kyse ja millaisia oikeuksia ja velvollisuuksia niihin liittyy. Prosessi eteni aineiston ja kirjallisuuden lukemisen ja tulkintojen rakentamisen vuoropuheluna. Teoria- ja tutkimuskirjallisuus auttoivat havaitsemaan ja jäsentämään kuvauksiin sisältyviä kokemuksiani. Tutkimuksellisten välineiden käyttö on tarkoittanut sitä, ettei kyse ole vain minun tutkijan kertomuksistani. Olen näitä välineitä käyttäen muuttanut päiväkirjojen sisältämät kuvaukset tutkimukseksi. (Ellis ym. 2011.) Kyse on myös sisällä olijan subjektiivisen kertomuksen ulkopuolisesta, jossain määrin objektiivisesta tarkastelusta kirjallisuuden avulla (Watts 2015).

Autoetnografisessa analyysissa tulkinta tapahtuu nykyhetkestä, vaikka päiväkirjamerkintöjen avulla palataankin aiempiin kokemuksiin ja ajatuksiin (Ettorre 2013). Tutkimus- ja tulkintaprosessilleni on ollut merkityksellistä muutos työurallani: siirryin yliopisto-opettajasta sosiaalityöntekijäksi ikäihmisten palveluihin. Vaihdos on vaikuttanut menneiden tapahtumien ja niiden kuvausten tarkasteluun sekä tutkimukseeni. Kyse on myös tutkimuksessa mukana olevista ajan ulottuvuuksista: menneisyydestä, nykyisyydestä, osin tulevaisuudesta (Juhila 2018). Jo työskentelyn aikana peilasin omia tutkijasosiaalityöntekijän kokemuksiani ja ajatuksiani aiempaan työuraani sosiaalityöntekijänä. Analyy$\sin$ ja tulkinnan vaiheessa mukana olivat myös nykyiset kokemukset, jotka aineiston keräämisen aikaan olivat tulevaisuutta.

\section{TUTKIJAKSI JA SOSIAALITYÖNTEKIJÄKSI KESKUKSEEN...}

\begin{abstract}
"Tiedote asukkaille
Olen Eeva Rossi ja koulutukseltani sosiaalityöntekijä. Työskentelen tällä hetkellä yliopisto-opettajana Lapin yliopiston sosiaalityön oppiaineessa. Aiemmin olen työskennellyt noin 15 vuotta sosiaalityöntekijänä (...) Olen myös aloittelemassa väitöskirjaani (...). 10.11.2014 olen aloittamassa osa-aikaisena sosiaalityöntekijätutkijana toimimisen asumispalvelukeskuksessa"

Ote tiedotteesta asukkaille
\end{abstract}

Toimimiseni Keskuksessa, itselleni uudessa yhteisössä, voidaan nähdä etno- 
grafiseen tutkimusperinteeseen liittyvänä kenttätyöskentelynä. Olin läsnä yhteisössä ja toimin siellä aktiivisesti. (Garthwaite 2016.) Kenttäjakso tarkoittaa toimintani fyysistä paikkaa, mutta myös toimintaan liittyviä kohtaamisia ja erilaisia suhteita (Emerson ym. 2001). Tutkimukseni suhteet liittyivät Keskukseen, sen henkilökuntaan ja asukkaisiin, joita tapasin henkilökohtaisesti sekä erilaisissa tilaisuuksissa että yhteisissä tiloissa. Keskuksessa asui noin 130 iäkästä asukasta. Henkilökohtaisesti tapasin 29 asukasta ja 13 omaista. Intensiivinen, päivittäinen toimiminen yhteisössä kesti kaksi viikkoa, jonka jälkeen se muuttui muutamana päivänä viikossa tapahtuvaksi, sitten kerran viikossa ja vähitellen noin kerran kuukaudessa tapahtuvaksi toiminnaksi. Kentällä olin yhteensä noin puoli vuotta.

Ennen toimintaani Keskuksessa laadin asukkaille ja henkilökunnalle tiedotteet ja kävin esittäytymässä eri tilaisuuksissa. Toimintaani perustelin sekä tutkimuksella että sosiaalityöllä. Kerroin omasta aiemmasta tutkimuksestani sekä Keskukseen liittyvästä tutkimusideastani. Toin esiin myös koulutukseni ja aiemman työkokemukseni sosiaalityöntekijänä ikäihmisten hoito- ja kuntoutuslaitoksessa sekä palveluasumisessa. Tällä perustelin asiantuntijuuttani ja osaamistani ikäihmisten kanssa työskentelyssä. Kyse oli eräänlaisesta sosiaalisesta positioinnista (Jensen-Hart \& Williams 2010), jossa näkyivät moraalinen positiointi tutkijan oikeuksineen ja velvollisuuksineen sekä subjektiivinen positiointi sosiaalityöntekijänä hankkimani oman kokemuksen kautta (van Lagenhove \& Harré 1999). Omat kokemukseni sosiaalityöntekijänä ja sitä myötä syntynyt ymmärrys ja arvostukset vai- kuttivat toimintaani, aineiston keräämiseen ja myös analysointiin (Scourfield 2001, 61-62). Vaikka juuri tämä yhteisö oli minulle lähes vieras, hyödynsin aiempaa kokemustani ja omaksumaani tapaa toimia iäkkäiden yhteisössä (Goffman 1971). Iäkkäiden yhteisöissä toimiminen ja sen tutkiminen oli minulle osittain tutun, arkisen tutkimista (ks. Eräsaari 1995, 48-49).

Päätin jo tutkimukseni suunnitteluvaiheessa, että kenttäjakson aikana toimin ensisijaisesti sosiaalityöntekijänä aktiivisesti asukkaiden kanssa ja jätän tutkijan roolin sivummalle. Tein tämän valinnan, koska olin kiinnostunut sosiaalityön tarpeesta asumispalveluissa, eikä yksikössä ollut sosiaalityöntekijää, jonka työtä seuraamalla olisin voinut saada tietoa aiheesta. Se, että korostin sosiaalityöntekijyyttä enemmän kuin tutkimusta, näkyy sanavalinnassani "sosiaalityöntekijätutkija", joka tutkimusprosessissa muuttui tutkijasosiaalityöntekijäksi. Sosiaalityöntekijätutkija-käsitteessä korostuvat interventio ja roolini yksilökohtaisen asiakastyön tekijänä (Garthwaite 2016). Tutkijasosiaalityöntekijä-käsite painottaa tutkimista ja sen mahdollistamista (esim. Pitkänen 2011). Toisaalta viitatessani tavoitteeseeni saada tietoa asukkaiden sosiaalityöllisistä tarpeista toin esiin asukkaiden roolin tiedontuottajina ja oman tarpeeni saada tietoa nimenomaan Keskuksesta. Tällöin korostui tutkimus, ei sosiaalityö.

Sosiaalityöntekijyys korostui myös siinä, että aloitteet asukkaiden ja omaisten tapaamisiin tulivat heiltä itseltään. He olivat kuulleet joko minulta tai henkilökunnalta mahdollisuudesta tavata sosiaalityöntekijätutkija. En tutkijana 
etsinyt tutkittavia. Minut haluttiin tavata, koska asukkailla oli tarve keskustella erilaisista ikääntyneen asukkaan arkeen liittyvistä asioista, kuten etuuksista, palveluista tai suhteista omaisiin (ks. Rossi 2018). Kohtaamiset poikkesivat tutkimuskohtaamisesta siinä, ettei minulla ollut valmiina haastattelukysymyksiä tai -teemoja, vaan tapaamiset rakentuivat asukkaiden tai heidän omaistensa esiin nostamista asioista.

Toimintani muuttui sosiaalityöstä tutkimukseksi, kun tallensin osan kohtaamisista äänitallenteiksi ja kirjoitin muistiinpanoja ja päiväkirjaa. Muistiinpanojen ja päiväkirjojen kirjoittaminen on mahdollista nähdä myös osana sosiaalityötä (Shaw \& Lunt 2018). Asiakaskohtaamisissa tehdään muistiinpanoja ja dokumentoidaan kohtaamisia. Olen sosiaalityöntekijän urani aikana pitänyt "työpäiväkirjaa" vaihtelevalla intensiteetillä. Identiteettiini sosiaalityöntekijänä on kuulunut päiväkirjojen kirjoittaminen, mutta kenttäjaksolla kirjoittaminen oli systemaattisempaa. Kirjoitukset oli jo lähtökohtaisesti tarkoitettu tutkimukseni aineistoksi, joten ne poikkeavat vain omaan käyttöön tarkoitetuista työpäiväkirjateksteistä. Vaikka olin ajatellut siirtää tutkijan roolin sivuun käytännönjakson ajaksi, päiväkirjojen kirjoittamisessa olin mukana myös tutkijana. Tällaista tiedon hankkimisen tapaa voidaan kutsua introspektioksi, jossa kyse on tutkimushetkellä tapahtuneesta itsensä havainnoimisesta (Rissanen 2015, 28).

\section{YHTEISÖN SISÄLLÄ, MUTTA}

ULKOPUOLELLA...

\begin{abstract}
Kovasti pohditutti päivän mittaan oma rooli, sillä puhe kaupungin kilpailuttamisesta, asiakkaista \& omaisista, osin itselle vierasta tapaa ja tämä ehkä pulmallista. Asettaudunko jotenkin organisaation vai omaisten tai jonkun muun väliin. En siis ole organisaation palkkalistoilla, mutta organisaation tärkeä osa.

10.11.2014 kotona
\end{abstract}

Aloittaessani kenttäjaksoa ajatuksenani oli, että olisin kiinteä osa yhteisöä. Kuten edellä olevasta sitaatista ja edellisessä luvussa olleesta esittelykirjeestäni näkyy, en työskennellyt organisaatiossa palkattuna työntekijänä, vaan "toimin" yhteisössä. Tämän eron tekeminen oli tärkeää organisaatiolle. Kyse oli työntekijän työoikeudellisiin ja osin myös toiminnallisiin oikeuksiin liittyvistä asioista. Palkkatyöni oli yliopistolla. Toiminta sanana liittyy enemmän tutkijan rooliin, kun taas sosiaalityöhön liittyy työskentely organisaatiossa viran- tai toimenhaltijana. En ollut organisaation virallinen työntekijä, vaan positioni virallisuus liittyi lupaani toimia tutkijana yhteisössä. Toimintalupa liittyi organisaation intressiin olla osana tutkimustani sekä saada sosiaalityöntekijä ja opiskelija yhteisöön (ks. vaihdosta Eräsaari 1995). Yhteisö oli siis osa tutkimustani, mutta ei "oma" työyhteisöni (ks. Gottwald ym. 2018). Tämä aiheutti pohdintaa sijoittumisestani erilaisiin välitiloihin. Toimin yhteisössä sisäpuolisena, mutta samaan aikaan olin tarkkaileva ulkopuolinen (Boyle 1994). Tilanteessani oli samankaltaisuutta Gottwaldin ym. (2018) kuvaileman marginaalinatiivin (marginal native) roolin kanssa. Tuolloin ollaan yhteisössä, mutta kaikki 
yhteisön asiat tai tehtävät eivät avaudu kuten täysin sisällä olevalle, natiiville, työntekijälle. Osaltaan ulkopuolisuudessa on kyse organisaation tapoihin, kulttuuriin ja arvoihin sitoutumisen asteesta (Garthwaite 2016).

Sairaanhoitajan kanssa keskustelimme omaisesta. Entistä vakuuttuneemmaksi tulen, että on vaikea toimia sos.tt:nä kun ei ole yhteisöä. Ei tunne historiaa ja joutuu pohtimaan, tekeekö jotain väärin, kun keskustelee ihmisten kanssa.

26.11.2014 Keskuksessa

Jakson alkuvaiheen päiväkirjatekstit kuvaavat kokemuksiani yhteisön ulkopuolisena sosiaalityöntekijänä olosta. Organisaatiot voidaan nähdä yhteisöinä,joihin liittyy yhteinen fyysinen ympäristö, mutta myös tunne yhteisöstä omine ideologisine tai institutionaalisine ymmärryksineen ja omine sosiaalisen kanssakäymisen muotoineen (Markuksela 2013). Minulla ei varsinkaan alkuvaiheessa ollut samanlaista institutionaalista ymmärrystä kuin Keskuksen työntekijöillä ja asukkailla. Toisaalta ulkopuolisen positioni auttoi havainnoimaan yhteisöön liittyvää sosiaalista kanssakäymistä esimerkiksi omaisten ja henkilökunnan välillä. Yllä oleva sitaatti on tilanteesta, jossa kohtasin erään asukkaan omaisen. Keskusteltuani työntekijöiden kanssa aloin pohtia, olinko sanonut omaiselle jotakin yhteisön näkökulmasta ongelmallista. Kyse on osaltaan pohdinnoistani työntekijän tai tutkijan asemoitumisesta suhteessa organisaatioon ja asiakkaisiin sekä siitä, toiminko tutkijana vai työntekijänä (Garthwaite 2016). Tutkijan rooliin kuuluu kriittisyys ja autonomia suhteessa organisaatioon ja erilaisiin in- tresseihin, mikä poikkeaa työntekijän roolista (Gottwald ym. 2018).

Keskus koostui tuetun asumisen, palveluasumisen ja tehostetun palveluasumisen yksiköistä, joissa pääosan tiloista muodostivat asukkaiden asunnot. Lisäksi yhteisössä oli yhteisiä, avoimia kokoontumistiloja, hoitajien kansliatiloja sekä toimisto-/vastaanottohuoneita.

Asiakkaita tapaamme heidän kotonaan tai yhteistiloissa. Onko siis niin, että ei ole tilallisesti selkeää paikkaa, vaan sekin muotoutuu joka kerta.

1.12.2014 illalla kotona

Omaa paikkaa organisaatiossa myös mietin. Se, ettei ole osa tiimiä, on merkittävä asia. Missään vaiheessa en ole ollut osa esim. työryhmiä, joissa voisi asioista keskustella. Rooli on enemmän konsultin rooli. Ehkä tulevaa kehittämistä ajatellen voisi miettiä olisiko mahdollista jotenkin oikeasti päästä mukaan työhön, siis kirjaamaan asioita, osallistumaan säännöllisiin tapaamisiin jne. 7.5.2015 kotona

Myös organisaation fyysiset tilat määrittivät positiotani. Edellä olevissa päiväkirjaotteissa näkyy, ettei minulla ollut jatkuvasti käytössäni tietokonetta, omaa työtilaa tai pääsyä asiakastietojärjestelmiin. Jo toimintaani aloittaessani tiesin, että tapaisin asukkaita pääsääntöisesti heidän kodeissaan eikä käytössäni olisi sosiaalityöntekijöille tyypillisiä työskentelytiloja ja -välineitä. Minulta puuttuivat sosiaalityön institutionaaliset tilat (Juhila 2018). Vaikka tämä oli minulla etukäteen tiedossa, vasta kenttäjaksoni aikana tiedostin materiaalisten ja teknisten tekijöiden merkityksen sosiaalityön arjessa ja käytännöissä. Se, ettei minulla ollut välineitä ja tiloja jatku- 
vasti käytössäni, tuo osaltaan näkyväksi näiden sekä organisaation merkityksen sosiaalityön käytännöille ja samalla korostaa tutkijan ulkopuolista positiota. Työhön liittyvät välineet ja tilat voidaan nähdä työntekijän virallisen aseman symboleina (Eräsaari 1995).

\section{Aiemmin olin mukana hoitajien viikko- kokouksessa, jossa monenlaista puhetta hoidettavista. Hivenen ulkopuolinen olo, vaikka olisi tehnyt mieli osallistua hoidon suunnittelukeskusteluun. Koska olen vain lyhyitä aikoja käymässä, en oikein pysty keskusteluun osallistumaan. \\ 25.11.2014 Keskuksessa}

Keskuksessa työskenteli pääosin terveydenhuollon ammattilaisia - sairaanhoitajia ja lähihoitajia. Vaikka gerontologisen sosiaalityön yhtenä toimintaympäristönä on nähty asumispalvelut (Koskinen \& Seppänen 2013), ei Keskuksessa työskennellyt sosiaalityöntekijää. Näin sosiaalityöntekijän läsnäolo yhteisössä oli uutta, ja siten sosiaalityöntekijän merkitys yhteisölle oli epäselvä. Ulkopuolisuuden kokemukseni kuvaa tätä epäselvyyttä. Tulkintaa vahvistaa episodi, josta olin kirjoittanut päiväkirjaani " $N y t$, kun teimme ensin puhelun Kelalle asiakkaan asiassa niin, että hoitaja(t) sen kuuli, niin tuntui, että asia tuotti enemmän yhteydenottoja". Jakson edetessä ulkopuolisuuden kokemukseni muutti muotoaan: toiset työntekijät alkoivat ottaa yhteyttä minuun, kun asukkaat tarvitsivat apuani, useimmiten etuuksiin tai palvelujärjestelmään liittyen. Positioni siirtyi ulkopuolisesta reunalla olijaksi. Omaan ulkopuolisuuteeni vaikutti myös osa-aikainen toimiminen yhteisössä, mikä toi epäsäännöllisyyttä läsnäolooni yhteisössä ja työntekijöille epätietoisuutta siitä, milloin olen pai- kalla. Kokemus ulkopuolisuudesta oli toimintaani rakennettu itsestäänselvyys, jota en osannut ennakoida omien aiempien sosiaalityöntekijän kokemusteni perusteella.

Moniammatillista yhteisöä tässä työssä kaipaa. Jälkimmäisessä asiakastapaamisessa oli puhetta harhoista ja tekisi mieli keskustella asiasta geriatrin tai vähintään hoitajan kanssa. (...) Saisi itselle ymmärrystä ja ehkä pystyisi jotain ratkaisua yhdessä hakemaan. $N y$ t on aika tavalla $y k s i n$ asioiden kanssa.

19.1.2015 Keskuksessa

Aiemmin toimiessani sosiaalityöntekijänä olin tottunut tiiviiseen moniammatilliseen työskentelyyn, jonka organisaatiorakenteet mahdollistivat. Työskentelytavan kaipuu kuvaa osaltaan aiemman työkokemukseni merkitystä. Kun menin uudelle, itselleni vieraalle kentälle, kannoin mukanani aiempia kokemuksiani ja niiden luomaa tapaa työskennellä ja tulkita tilanteita (Goffman 1971). Kyse on myös moraalisen position (oikeuksien ja velvollisuuksien) ja persoonallisen position (aiempien kokemusten) välisestä jännitteestä. Keskuksen johto oli kannustanut yhteiseen tekemiseen ja keskusteluun, mutta varsinaisia rakenteita, kuten moniammatillisia kokouksia, ei ollut enkä onnistunut niitä myöskään itse osallistumisellani luomaan. Toisaalta jo alussa oli sovittuna, että kohtaamisissani asukkaiden kanssa kysyin heiltä lupaa olla yhteydessä yksikön muuhun henkilökuntaan. Kohtaamisten luottamuksellisuus ja oikeus yksityisyyteen ovat tutkimuksen ja sosiaalityön proseduraaliseen etiikkaan liittyviä keskeisiä periaatteita (Ellis 2007). Jos asukkaat eivät antaneet lupaa eikä oikeutta yhteydenpitoon, eivät yhteisön työntekijät tienneet, keitä 
kohtasin. Tuolloin en pystynyt hyödyntämään yksikön moniammatillisuutta. Kun asukkaat antoivat luvan keskustella tilanteestaan hoitajan tai fysioterapeutin kanssa, se mahdollisti keskustelun asukkaan tilanteesta ja minulle tunteen yhteisöön kuulumisesta.

\section{...JA ASUKKAAN ELÄMÄSSÄ RINNALLA KULKEMASSA}

Kohtaamiset asukkaiden kanssa nojautuivat tietooni ja kokemukseeni sosiaalityöstä. Kohtaamisissa organisaatioon kuulumattomuus saattoi olla etu: kanssani saattoi puhua asioista, joita yhteisön jäsenelle ei ehkä puhuttaisi. Koska toimintaani liittyi tutkimuksellinen ulottuvuus enkä ollut organisaation työntekijä, ei organisaatio myöskään määrittänyt toimintaani tai asukaskohtaamisten sisältöjä ja tarkoitusta.

Aamulla kävin Tellervon luona. Varsinaisesti hänellä ei ollut mitään asiaa, mutta olipas huonosti kirjoitettu. Siis hän halusi puhua yleensä elämästään, perheestään ja lapsistaan. Kysyin erikseen sitä, että miltä juttelu on tuntunut ja oli kuulemma tuntunut hyvältä. Ei ole kenen kanssa puhua. (...) Tietenkin kun ei ole organisaation asettamia rajoja, voi vapaasti lähteä siitä liikkeelle, mitä ihmiset kertovat. Ja myös antaa aikaa. 7.5.2015 kotona

Kirjoitan otteessa, ettei asukkaalla "ollut mitään asiaa", vaikka samalla tulkitsen toteamuksen kuvaavan huonosti tilannetta. Kohtaamiset asukkaiden kanssa lähtivät liikkeelle heille merkityksellisistä asioista. Heillä oli oikeus päättää siitä, mitä he minulle kertoivat. Tellervolla oli tarve keskustella perheensä tilanteesta ja omasta elämänhistorias- taan. Hän otti johdon tilanteessa (ks. Granfelt 2004, 142). Vaikka Tellervo ei osannutkaan todeta, oliko tapaamisesta "hyötyä", hän toivoi useita tapaamisia. Tutkijasosiaalityöntekijänä olin kiinnostunut ihmisten tarinoista sekä heidän avun tarpeistaan. Vaikka elämäntarinan kuuntelu ja yhdessä jäsentäminen on asiakkaiden auttamista, en kokenut sitä tuossa hetkessä merkitykselliseksi sosiaalityöksi (Juhila 2018).

Tulin Santerin luota, soitin kaupungin sosiaalitoimistoon ja varasimme Santerille sosiaalityöntekijälle ajan heinäkuun toimeentulotukea varten. Samalla saavat tarkastella pitemmällekin asiaa. Kirjoitin Santerille ylös mitä tarvitsee ottaa mukaan. Pankissa hänen täytyy käydä. Varasimme ajan pankkiin sekä tiliote + lainamäärä asiaa, että lainanjärjestelyjä varten. Edunvalvojasta puhuimme mutta Santeri jäi edelleen asiaa miettimään. Sovimme, että laitan sos.tt:lle viestin, jossa kerron tilanteesta: edunvalvoja, pankkiasiat, kuljetuskin.

16.7.2015 Keskuksen pihalla

Sosiaalityöntekijänä toimiminen tarkoitti myös asukkaiden asioiden hoitamista, kuten edellä Santerin asioiden järjestelemistä. Sekä Tellervon että Santerin kanssa työskentelyä kuvaavista päiväkirjateksteistä näkyy, että olin asettanut toiminnalleni tavoitteita sosiaalityön lähtökohdista: halusin jollakin tavoin auttaa asukkaita, muuttaa heidän tilanteitaan ja ratkaista ongelmia. Ajatus asukkaiden auttamisesta ja heidän tarpeisiinsa vastaamisesta sosiaalityön keinoin oli sisäänrakennettuna toimintaani. Kyse oli tällöin sitoutumisestani asukkaisiin, heidän omaisiinsa sekä myös koko yhteisöön. Tämä tarkoitti ulkopuolisen tutkijan position hyl- 
käämistä (Sherif 2001). Kohtaamisessa Santerin kanssa valmistelin hänen ja kaupungin sosiaalityöntekijän tapaamista. Asemani suhteessa palvelujärjestelmään oli epävirallinen. Sosiaalityön etiikkaan ja asemaani liittyen velvollisuuteni oli toimia asukkaiden ja heidän omaistensa rinnalla, kanssa ja puolesta, mutta minulla ei ollut päätöksenteon oikeutta heidän asioissaan.

Tänään olin n. 3 tuntia Birgitan luona. Keskustelimme ensin viimeaikaisista tapahtumista eli viime viikon lääkärissä käynnistä sekä Kelan kirjeestä liittyen matkakorvauksiin. (...) Kysyin Birgitalta, haluaako hän, että tallennan haastattelun, mutta ei halunnut. Tosin ilmeisesti hän luuli minun nauhoittaneen, koska soitti illalla ja kysyi, nauhoitinko. Kerroin, että en. Birgitta oli huolissaan siitä, ettei tieto vain leviä, koska kertoi miehestään sekä lapsistaan. Totesin Birgitalle, että hän on hyvä kertoja ja että sen vuoksi harmittaa, etten nauhoittanut. Olisi pitänyt paremmin kysyä ja alkaa nauhoittaa.

\subsubsection{5 kotona illalla}

Päiväkirjaote kuvaa tapaamistani Birgitan kanssa, joka ei antanut lupaa keskustelujemme tallentamiseen, mutta sain luvan tehdä muistiinpanoja. Kohtaamisessamme painottui sosiaalityöntekijyys, johon liittyi asukkaan tarinan kuunteleminen ja tuen antaminen. Myös tutkijana olin kuuntelija. Kuten otteesta tulee esiin, tutkijana olisin ollut kiinnostunut tallentamaan kohtaamisemme. Vaikka etnografisen tutkimuksen ja sosiaalityön menetelmissä ja lähtökohdissa on samankaltaisuutta, kuten holistisuus, elämäntarinallisuus ja havainnointi (Haight ym. 2014, 128), niiden tavoitteet ovat erilaisia.
Tutkijan tavoitteet ovat abstrakteja ja liittyvät ilmiön ymmärtämiseen ja käsitteellistämiseen. Tutkijan roolissa olin kiinnostunut näkemään ja kuulemaan tutkittavia ja sen myötä luomaan uutta tietoa. Sosiaalityössä, samoin kuin Keskuksen asukkailla ja minulla sosiaalityöntekijän roolissa, tavoitteet liittyvät arjen usein konkreettisten ongelmien ratkaisemiseen. (Mikkonen ym. 2016.) Myös sosiaalityössä ollaan kiinnostuneita kohdattavien asiakkaiden, tai tässä asukkaiden, tiedosta, heidän tarinoistaan ja mahdollisista ongelmistaan (Juhila 2018), mutta tätä tietoa käytetään asiakkaiden auttamiseksi ja heidän tilanteidensa muuttamiseksi.

\begin{abstract}
Asiakas oli etsinyt valmiiksi monenlaisia kuitteja ja papereita. Niiden pohjalta teimme hakemuksen, alustavasti minä kirjoitan hakemuksen liitteen vielä erikseen. Asiakas keitti kahvit ja tarjosi kaikkea: piirakkaa, juustoa, karkkia. Keskustelukin oli hyvin epämuodollista. Kertoikin elämästään ja kuuntelimme tarinoita asiakkaan ja hänen omaisensa lapsuudesta ja nuoruudesta. Noin 11/2 tuntia meni aikaa, mutta mukavaa ja toivottavasti hyödyllistä oli.

19.11.2014 kotona illalla
\end{abstract}

Tapasin asukkaita useimmiten heidän asunnoissaan, jotka yhteisössä sijaitsemisesta huolimatta olivat asukkaiden koteja. Koti on tutkimuksessa ja gerontologisessa sosiaalityössä keskeinen kohtaamispaikka (Koskinen \& Seppänen 2013; Granfelt 2004, 145-146; Autonen-Vaaraniemi 2009). Koti on tila, jota sen asukkaat hallitsevat (Juhila 2018). Myös koti tilana määrittää osallistujien positioita. Jokainen kohtaaminen oli erilainen ja rakentui asukkaiden lähtökohdista. Asukkaat saattoivat tarjota kahvia, kuten edellä, tai pyytää 
minua antamaan heille juomista jääkaapista, tai sitten saatoimme istua virallisesti keittiön pöydän ääressä erilaisten dokumenttien ja hakemusten äärellä. Käynneillä olin joko työntekijä, tutkija tai vieras, joskus kaikkia näitä. Asukkaalla, olipa hän asiakas tai tutkittava, oli valtaa päättää kohtaamisen koreografia sekä määrittää siihen liittyviä suhteita ja aiheita sekä kohtaamisen rakentumista (Juhila 2018; AutonenVaaraniemi 2009).

Ellis (2007) on pohtinut omien tutkimuskohtaamisten etiikkaa. Hän on yhtäältä nähnyt tutkijan vierailijana ja toisaalta ystävänä. Näihin voidaan nähdä liittyvän erilaiset oikeudet ja velvollisuudet. Edellä kuvaan tilannetta, jossa asiakas tarjosi kahvia. Santeri, jota tapasin useita kertoja, kutsui minut syntymäpäivilleen. Situationaalisen etiikan näkökulmasta kuvaamassani tilanteessa kieltäytyminen kahvista ei olisi ollut oikein. Kun tarjoiluja, kutsua syntymäpäiville tai intiimin kokemuksen ja tiedon jakamista tarkastellaan relationaalisen etiikan näkökulmasta, ei tilanne näytä yksinkertaiselta. Esiin nousee kysymys: muistavatko tutkittavat, että suhteessa on kyse tutkimuksesta, tai tässä tapauksessa myös sosiaalityöstä, ei suoranaisesti ystävyydestä (mt.). Vaikka olin sitoutunut asukkaisiin ja heidän auttamiseensa, ei kyse ollut ystävyyden kaltaisesta sitoutumisesta. Kohtaamisiin liittyi vastavuoroisuutta, koska tapaani toimia liittyy se, että voin jakaa kokemuksiani ja paloja elämästäni tutkittaville ja arkityössäni asiakkaille. Olennainen kysymys on, muistavatko osallistujat, että heidän kertomansa tieto tulee osaksi tutkimustani (ks. Ellis 2007). Pohtiessamme asukkaiden arjen pulmia tai mennyttä elämää kohtaaminen ei vält- tämättä näyttäytynyt tutkimuksena. Se, että asetin useissa tapaamisissa nauhurin esille, muistutti kuitenkin tapaamisen tutkimuksellisuudesta.

\section{LOPUKSI: MONENLAISISSA POSITIOISSA}

Tämän tutkimuksen kohteena oli toimintani tutkijasosiaalityöntekijän kaksoisroolissa: tutkijana ja sosiaalityöntekijänä.Ajatuksenani oli tarkastella roolien yhdistämisen mahdollisuuksia sekä sitä, mistä paikasta käsin tutkimukseni tuottaa tietoa.Artikkelini osallistuu osaltaan keskusteluun sosiaalityöntekijän tutkijana ja kirjoittajana toimimisesta sekä tiedon tuottamisesta ja tiedon tuottamisen paikoista (esim. Mutka 1998; HE 5/2020). Olen tarkastellut tutkimuksessani tutkijasosiaalityöntekijän kokemuksiani ja positioitani suhteessa toiminnan sosiaaliseen ympäristöön. Positioiden tarkastelu tarkoitti tutkijasosiaalityöntekijänä toimimiseeni liittyvien oikeuksieni ja velvollisuuksieni (moral positioning), mutta myös kenttäjakson ja aiempien kokemuksieni (personal positioning) analysointia (Harré ym. 2009; van Lagenhove \& Harré 1999). Kaksoisrooliini liittyneet erilaiset positiot paikantuivat toisiinsa linkittyviin, osittain jännitteisiin, käsitteellisiin vastinpareihin: virallinen - epävirallinen, ulkopuolinen - sisäpuolinen ja neutraali - hyvän tuottaja. Muodostin vastinparit tarkastelemalla tutkijan ja sosiaalityöntekijän rooleja suhteessa yhteisöön sekä siellä toimimiseen. Vastinpareista ensimmäinen kuvaa tutkijan ja sosiaalityöntekijän asemaani yhteisössä, toinen enemmänkin kokemuksiani paikastani yhteisössä sekä kolmas toimintaani ja tutkimusprosessia. Positioiden moninaisuus kuvaa tutkijasosiaalityöntekijän 
toimimisen ja tiedon tuottamisen paikkojen tilannekohtaisuutta ja moninaisuutta.

Virallisen ja epävirallisen vastinpari paikantaa positiotani suhteessa organisaatioon. Siinä korostuvat tutkijasosiaalityöntekijän oikeudet ja velvollisuudet (moral positioning; van Lagenhove \& Harré 1999).Virallisuus liittyy asemaani tutkijana, tutkimusluvan myötä saamaani oikeuteen olla läsnä ja kerätä tietoa yhteisössä sekä velvollisuuteeni toimia tutkijan eettisiä periaatteita noudattaen. Epävirallisuus liittyy asemaani sosiaalityöntekijänä ja siihen, etten ollut tutkijasosiaalityöntekijänä organisaation työntekijä. Positiooni ei liity samanlaisia työyhteisöllisiä oikeuksia ja velvollisuuksia kuin (sosiaali)työntekijöillä. Kun en ollut organisaation työntekijä, ei minulla ollut oikeutta käyttää työntekijyyttä symbolisoivia välineitä, kuten asiakastietojärjestelmiä. Toisaalta epävirallisuuden myötä organisaatio ei myöskään määritellyt toimintaani, sen sisältöjä tai käytettyä aikaa, vaan nämä rakentuivat enemmänkin omille aiemmille kokemuksilleni ja yksilöllisille toimintatavoilleni, persoonalliseen positiointiin (van Lagenhove \& Harré 1999).

Vastinpari "ulkopuolinen - sisäpuolinen" luonnehtii suhdettani työyhteisöön ja asukkaisiin. Tässä parissa painottuvat kokemuksellisuus ja yksilölliset tekijät (personal positioning; van Lagenhove \& Harré 1999). Ulkopuolisuus liittyy epävirallisuuteen: epävirallisuus tuotti kokemukseni ulkopuolisuudesta, joka kuvaa työyhteisöstä erillään oloani. Olin marginaalinatiivi (Gottwald ym. 2018). Tämä kokemus oli itselleni ennakoimaton, vaikka se oli osin rakennettuna toimintaani heti alusta: kävin yhteisössä ajoittain, minulla ei ollut omaa tilaa ja tiedossa oli myös toimintani määräaikaisuus. Kokemuksen ennakoimattomuus tekee näkyväksi toimintani ja positioni rakentumisen kiinnittymisen aiempaan tietooni ja kokemukseeni, yksilöllisiin tekijöihin. Ulkopuolisuuden kokemukseni korostaa toimintaani tutkijan roolissa, johon voidaan liittää ulkopuolisena tarkkailijana oleminen. Toisaalta, koska tutkimukseni nojautuu autoetnografiaan ja itsepositiointiin, paradoksaalisesti ulkopuolisuuden kokemus ei ollut tarkkailijan kokemus vaan enemmänkin tutkimuksessa sisällä olijan kokemus ja tunne.

Suhteessa asukkaisiin positiotani kuvaa kokemus sisäpuolisuudesta, joka liittyi asukkaiden minulle antamaan oikeuteen päästä hetkeksi heidän elämäänsä. Oikeus mahdollistui tutkijan virallisen positioni kautta. Sisäpuolisuuteen liittyivät sitoutuminen asukkaisiin, heidän rinnallaan oleminen, tuen antaminen ja auttaminen arjen asioissa. Ne voidaan nähdä gerontologiseen sosiaalityöhön liittyvinä velvollisuuksina ja tehtävinä (Koskinen \& Seppänen 2013). Sisäpuolisen positiossa näkyy nojautuminen paitsi sosiaalityöhön liittyviin oikeuksiin ja velvollisuuksiin, myös persoonalliseen positiointiin eli koulutukseni ja aiempien kokemuksieni tuottamaan ymmärrykseen sosiaalityöntekijyydestä.

Viimeinen vastinpari "hyvän tuottaja neutraali" kuvaa toimintani luonnetta. Hyvän tuottaminen on yhteydessä sisäpuolisen positiooni ja kiinnittyy gerontologisen sosiaalityön tehtäviin ja eettisiin velvollisuuksiin toimia auttajana ja tukijana. Hyvän tuottaja kuvaa 
toimintani sosiaalityöntekijyyttä, jossa olen hylännyt objektiivisena tutkijana olemisen (Sherif 2001). Neutraali kuvaa toimintaani tutkijana ja on yhteydessä ulkopuolisuuteen. Tutkimuksessani neutraalius tarkoittaa erityisesti analyysivaiheessa itseni etäännyttämistä ja tutkijan näkökulman tuottamista kokemuksistani. Tutkijan perinteiseen rooliin on liitetty velvollisuus toimia objektiivisesti ja neutraalisti suhteessa tiedon tuottamiseen ja tutkittaviin ilmiöihin tai ihmisiin (Boyle 1994; Markuksela 2013). Kuten AutonenVaaraniemi $(2009,75)$ toteaa, ei objektiivisena tutkijana toimiminen ole helppoa, eikä se ole aina tavoitteenakaan. Tutkijan velvollisuuksiin ja eettisiin vastuisiin voidaan liittää myös tutkittavien auttaminen ja heidän tarpeisiinsa vastaaminen (esim. Mikkonen ym. 2016). Vastinpari "hyvän tuottaja - neutraali” kuvaa myös sosiaalityön ja tutkimuksen erilaisia tavoitteita. Sosiaalityön tavoitteet liittyvät elämän konkreettisiin ongelmiin ja tutkimuksen abstrakteihin ilmiöihin (Mikkonen ym. 2016; Holstein \& Gubrium 2000).

Autoetnografia mahdollisti omien kokemusteni ja niihin liittyvien tunteideni tarkastelun. Se vaati kuitenkin rinnalleen teoreettisia välineitä, jotta tutkijan kokemukseni muuntuivat tutkimukseksi. (Watts 2015; Ellis ym. 2011.) Teoreettiset välineet, kuten tässä tutkimuksessa positioteoria, auttavat havaitsemaan ja jäsentämään arkiseen ymmärrykseen ja käytäntöihin liittyviä tekijöitä. Positioteoria teki näkyväksi tutkijasosiaalityöntekijän toimintaani liittyvät moraaliset ja persoonalliset positioinnit (van Lagenhove \& Harré 1999). Sekä sosiaalityön käytäntöihin että tutkimukseen ja niihin kuuluviin kohtaamisiin liittyy tiedon tuottaminen erilaisista positioista. Asiakkaat ja työntekijät, tutkittavat ja tutkijat tuottavat tietoa omista vaihtuvista positioistaan, joihin liittyvät erilaiset oikeudet ja velvollisuudet sekä yksilölliset tekijät. Tutkimuksessani positioiden erilaisuus kuvaa tutkijan, mutta myös sosiaalityöntekijän, asemoitumisen eroja suhteessa tiedon tuottamisen paikkaan, asukkaisiin ja organisaatioon. Positioiden havaitseminen ja niiden rakentumisen ymmärtäminen on tärkeää tilanteiden ja tuotetun tiedon ymmärtämiseksi ja tulkitsemiseksi sosiaalityön tutkimuksessa ja käytännöissä. Positioteoria mahdollistaisi laajemminkin gerontologisen sosiaalityön käytäntöjen jäsentämisen. Sen avulla voisi tarkastella esimerkiksi puuttumista iäkkäiden elämäntilanteeseen, kuten kaltoinkohteluun, ja puuttumiseen liittyviä oikeuksia, velvollisuuksia ja toimijoiden yksilöllisiä tekijöitä.

Positioiden linkittyminen toisiinsa tekee näkyväksi sosiaalityöntekijän ja tutkijan sijoittumisen asukkaiden ja organisaation väliin. Niiden moninaisuus kuvaa osaltaan vaikeutta yhdistää tutkijan ja sosiaalityöntekijän rooleja, joihin liittyy erilaisia oikeuksia, velvollisuuksia, tehtäviä ja paikkoja. Hankkeissa ja tutkimuksissa, joissa on yhdistetty sosiaalityön käytäntöjä ja tutkimusta, on sosiaalityöntekijä usein siirtynyt asiakastyön arjesta tutkijan tehtäviin (esim. Pitkänen 2011; Uggerhøj 2011; Julkunen 2011). Myös tämän tutkimuksen perusteella näyttäisi arkisten kokemusten muuntuminen tutkimukseksi vaativan etäisyyden ottamista kokemuksiin sekä tutkittavaan yhteisöön eli irrottautumista sosiaalityön arkisista käytännöistä. Tässä tutkimuksessa sosiaalityön 
käytäntöihin siirtyi tutkija ja opettaja. Tämä asetelma mahdollistaa tutkimuksen tiiviin yhteyden asiakkaiden arkeen ja sosiaalityön käytäntöihin sekä näin tuotetun kokemuksellisen tiedon sisällyttämisen tutkimukseen ja myös opetukseen.

\section{ViITTEET}

1 Artikkelini käsikirjoitusta ovat kommentoineet anonyymit arvioitsijat sekä professorit Merja Laitinen ja Marjaana Seppänen, joille suuret kiitokset. Kriittiset ja tarkat kommentit edistivät kirjoittamistani ja mahdollistivat artikkelin valmistumisen.

2 Käytännönopettajina toimivat laillistetut sosiaalityöntekijät. Opiskelijan käytännön jakso oli 5 viikkoa, josta olimme yhdessä Keskuksessa neljä viikkoa. Minun toimintani jatkui jakson jälkeenkin.

3 Tutkimukseni proseduraaliseen etiikkaan liittyvät kysymykset ratkaisin pyytämällä ja saamalla tutkimusluvan Keskusta ylläpitävältä yhdistykseltä. Lisäksi sain luvan jokaiselta henkilökohtaisesti tapaamaltani asukkaalta. Tutkimukseen osallistuvien tunnistettavuutta olen estänyt muuttamalla heidän nimensä ja jättämällä Keskuksen nimeämättä.

\section{KirJALlisuUs}

Andersson, Leon (2006) Analytic autoethnography. Journal of Contemporary Ethnography, 35 (4), 373-395. https://doi. org/10.1177/0891241605280449

Autonen-Vaaraniemi, Leena (2009) Eronneiden miesten kodit ja kotikäytännöt. Acta Universitatis Tamprensis 1445. Tampere:Tampereen Yliopisto.

Boyle, Joyceen S. (1994) Styles of ethnography. Teoksessa Janice M. Morse (toim.) Critical issues in qualitative research methods. Thousand Oaks: SAGE, 159185.

Chang, Heewon \& Ngunjiri, Faith \& Her- nandez, Kathy-Ann C. (2012) Collaborative autoethnography. London \& New York: Routledge.

Driessens, Krister \& Saurama, Erja \& Fargion, Silvia (2011) Research with social workers to improve their social interventions. European Journal of Social Work 14 (1), 71-88. https://doi.org/10.1080/ 13691457.2010.516629

Ellis, Carolyn (2007) Telling secrets, revealing lives: Relational ethics in research with intimate others. Qualitative Inquiry 13 (1), 3-29. https://doi. org $/ 10.1177 / 1077800406294947$

Ellis, Carolyn \& Bochner, Arthur P (2006) Analyzing analytic autoethnography: An autopsy. Journal of Contemporary Ethnography 35 (4), 429-449.

Ellis, Carolyn \& Adams, Tony \& Bochner, Arthur P. (2011) Autoethnography: An Overview. Forum: Qualitative Social Research, 12 (1), Art 10. https://doi. org/10.1177/0891241606286979

Ellis, Carolyn \& Flaherty, Michael G. (1992) An agenda for the interpretation of lived experience. Teoksessa Carolyn Ellis \& Michael G. Flaherty (toim.) Investigating subjectivity. Research on lived experience. Newsbury Park: Sage Publications, $1-13$

Emerson, Robert M. \& Fretz, Rachel I. \& Shaw, Linda L. (2001) Participant observation and fieldnotes. Teoksessa Paul Atkinson, Amanda Coffey, Sara Delamont, John Lofland \& Lyn Lofland (toim.) Handbook of ethnography. London: Sage Publications, 352-368. https://doi. org/10.4135/9781848608337.n24

Eräsaari, Leena (1995) Kohtaamisia byrokraattisilla näyttämöillä. Helsinki: Gaudeamus.

Ettorre, Elizabeth (2013) Drug user researchers as autoethnographers: "Doing reflexivity" with women drug users. Substance Use \& Misuse 48 (13), $1377-$ 1385. https://doi.org/10.3109/1082608 4.2013.814999

Garthwaite, Kayleigh (2016) The perfect fit? Being both volunteer and ethnographer in a UK foodbank. Journal of Organizational Ethnography 5 (1), 60-71.

Goffman, Erving (1971) Arkielämän roolit. Suom. Erkki Puranen. WSOY: Helsinki.

Gottwald, Markus \& Sowa, Frank \& Si- 
mon, Georg (2018) "Walking the line": an at-home ethnography of bureaucracy. Journal of Organizational Ethnography 7 (1), 87-102. https://doi.org/10.1108/ JOE-10-2016-0021

Granfelt, Riitta (2004) Hetkeksi jaetut maailmat? Kokemuksia vankilasta ja tuetun asumisen yhteisöstä. Janus 12 (2), 134-154.

Haight, Wendy \& Kayama, Misa \& KorangOkrah, Rose (2014) Ethnography in social work practice and policy. Qualitative Social Work 13 (1), 127-143. https:// doi.org/10.1177/1473325013507303

Harré, Rom \& Moghaddam, Fathali M. \& Cairnie Pilkerton, Tracy \& Rothbart, Daniel \& Sabat, Steven R. (2009) Recent advances in positioning theory. Theory \& Psychology 19 (1), 5-31. https://doi. org/10.1177/0959354308101417

HE 5/2020 vp. Hallituksen esitys eduskunnalle laiksi sosiaalihuoltolain muuttamisesta. https://www.eduskunta. fi/FI/vaski/HallituksenEsitys/Sivut/ HE_5+2020.aspx. Luettu 1.3.2020.

Holstein, James, A. \& Gubrium, Jaber F. (2000) Constructing the life course. Second edition. New York: General Hall Inc.

Jensen-Hart, Staci \& Williams, D. J. (2010) Blending voices: Autoethnography as a vehicle for critical reflection in social work. Journal of Teaching in Social Work 30 (4), 450-467. https://doi.org/10.108 0/08841233.2010.515911

Juhila, Kirsi (2018) Aika, paikka ja sosiaalityö. Tampere:Vastapaino.

Julkunen, Ilse (2011) Knowledge-production processes in practice research - outcomes and critical elements. Social Work \& Society 9 (1), 60-75.

Koskinen, Simo \& Seppänen, Marjaana (2013) Gerontologinen sosiaalityö. Teoksessa Eino Heikkinen, Jyrki Jyrkämä \& Taina Rantanen (toim.) Gerontologia. Helsinki: Duodecim, 444-453.

Markuksela, Vesa (2013) "Aisti kuin kala" Etnografia vetouistelun veljeskunnan kilpailukäytännöistä. Rovaniemi: Lapin yliopistokustannus.

Mikkonen, Enni \& Laitinen, Merja \& Hill, Cath (2016) Hierarchies of knowledge: Analyzing inequalities within social work ethnographic research process as ethical notions in knowl- edge production. Qualitative Social Work 16 (4), 515-532. https://doi. org/10.1177/1473325016629542

Mutka, Ulla (1998) Sosiaalityön neljäs käänne. Asiantuntijuuden mahdollisuudet vahvan hyvinvointivaltion jälkeen. SoPhi. Jyväskylä: Jyväskylän yliopisto.

Pitkänen, Miia (2011) Vastuun paikka! Vanhempien tukeminen lapsen huostaanotossa. Soccan ja Heikki Waris -instituutin julkaisusarja nro 26.

Rissanen, Päivi (2015) Toivoton tapaus? Autoetnografia sairastumisesta ja kuntoutumisesta. Kuntoutussäätiön tutkimuksia 88/2015. Helsinki: Kuntoutussäätiö.

Ronkainen, Suvi (1999) Ajan ja paikan merkitsemät. Subjektiviteetti, tieto ja toimijuus. Helsinki: Gaudeamus.

Rossi, Eeva (2018) Asumispalvelukeskuksen iäkkäiden asukkaiden avun ja tuen tarpeet. Gerontologia 32 (4), 235-251. https://doi.org/10.23989/gerontologia. 75745

Satka, Mirja \& Karvinen-Niinikoski, Synnöve \& Nylund, Marianne 2005: Mitä sosiaalityön käytäntötutkimus on? Teoksessa Mirja Satka, Synnöve KarvinenNiinikoski, Marianne Nylund \& Susanna Hoikkala (toim.) Sosiaalityön käytäntötutkimus. Helsinki: Palmenia-kustannus, 9-19.

Scourfield, Jonathan (2001) Interviewing interviewers and knowing about knowledge. Teoksessa Ian Shaw \& Nick Gould (toim.) Qualitative research in social work. London: Sage Publications, 60-72. https://doi. org/10.4135/9781849209694.n4

Shaw, Ian \& Lunt, Neil (2018) Forms of practitioner research. British Journal of Social Work 48 (1), 141-157. https:// doi.org/10.1093/bjsw/bcx024

Sherif, Bahira (2001) The ambiguity of boundaries in the fieldwork experience: establishing rapport and negotiating insider/outsider status. Qualitative Inquiry 7 (4), 436-447. https://doi. org/10.1177/107780040100700403

Uggerhøj, Lars (2011) What is practice research in social work - definitions, barriers and possibilities. Social Work \& Society 9 (1), 45-59. https://doi. org/10.1921/095352211X604318 
van Lagenhove, Luk \& Harré, Rom (1999) Introducing positioning theory. Teoksessa Rom Harré \& Luk van Langenhove (toim.) Positioning Theory: Moral context of intentional action. Oxford: Blackwell Publishers 1td., 14-31.

Vincett, Joanne (2018) Researcher self-care in organizational ethnography: Lessons from overcoming compassion fatigue. Journal of Organizational Ethnography 7 (1), 44-58. https://doi.org/10.1108/ JOE-09-2017-0041
Watts, Lynelle (2015) An autoethnographic exploration of learning and teaching reflective practice. Social Work Education 34 (4), 363-376. https://doi.org/10.108 0/02615479.2015.1016903

Witkin, Stanley (2014) Preface. Teoksessa Stanley L. Witkin (toim.) Narrating social work through autoethnography. New York: Columbia University Press, xi-xiv. https://doi.org/10.7312/witk15880 